\title{
Fløteskummernes inntog
}

\author{
Hvordan og hvorfor ble det naturlig at selskaper som Adecco og Incita drifter sykehjem? Kanskje et tilbake- \\ blikk på 20 års modernisering av norsk offentlig sektor kan gjøre det lettere å forstå?
}

Mediene har avdekket ulovlig underbetaling på det ene sykehjemmet etter det andre. Kanskje kan et historisk tilbakeblikk gi litt av foklaringen på hvorfor dette har oppstått?

Mange har lest Norman-utvalgets 20 år gamle utredning Mot bedre vitende? Effektiviseringsmuligheter $i$ offentlig sektor (1). Under ledelse av professor Victor D. Norman laget utvalget en strategi for en omdanning som ennå ikke er fullført. Rent språklig utfordret ikke Norman den allment godtatte velferdsstatsmodellen. Han lanserte bare nye ord for at flere skulle se det fornuftige $i$ at Adecco og andre private overtar det som før var offentlig.

Selve ordet «privatisering» ble et fyord. Konkurranseutsetting klinger bedre. Milde ord som «fristilling» og «fritt brukervalg» beskriver omdanningen fra kommunalt til kommersielt. Fri rett til å velge høres da bra ut? Hvem vil ha byråkratisk dirigering og tvang? Da byrådet la frem bystyremeldingen Konkurranse og kvalitet i Oslo kommune (2), behandlet i bystyret 21.10. 1998, ville hovedstadens Høyre-byråd «bidra til at kommunens tjenesteproduksjon blir mest mulig kostnadseffektiv og kvalitetsriktig, uansett om denne fysisk utføres av kommunale eller utenforstående aktører.» Hvem kan være uenig i det?

\section{Bestemor på anbud?}

To år senere sluttet sosialminister Guri Ingebrigtsen (Ap) seg til det tverrpolitiske koret som gjentok den samme sangen.
I et intervju ble hun spurt om hun ikke ville advare mot at man satte bestemor ut på anbud. Hun svarte: «Jeg er opptatt av at bestemor får de beste tjenestene. Ikke av hvem som yter dem. Det vi aldri må gi fra oss, er at det offentlige har ansvaret.» (3). i desember 2000, var «helserevolusjonen» i gang. Dagen etter stiftet to leger og en finansmann et nytt aksjeselskap. De så mulighetene når Arbeiderparti-regjeringen ville slippe til private selskaper som underleverandører. De satset forsiktig. Som

\section{«Egentlig er det selvinnlysende at denne formen for modernisering fører til lov- og tariffstridig underbetaling»}

Siden har dette har vært statlig politikk. Når det gjelder privatisering, har Arbeiderpartiets statsministre hatt størst gjennomføringsevne. Samtidig virker Jens Stoltenberg takknemlig for at Erna Solberg og Siv Jensen prøver å gi velgerne et annet inntrykk. Den felles parolen er ny offentlig styring - inspirert av Thatchers og Blairs «new public management».

Arbeiderpartiets sykehusreform i 2001 som Høyre og Fremskrittspartiet sluttet entusiastisk opp om - viste hvordan det kan gjøres. Smarte investorer og dyktige leger fikk anledning til å skumme privat fløte av helsebevilgningene.

\section{Helserevolusjon}

Da helseminister Tønne innkalte til «kick off»-arrangement på sykehuset i Drammen

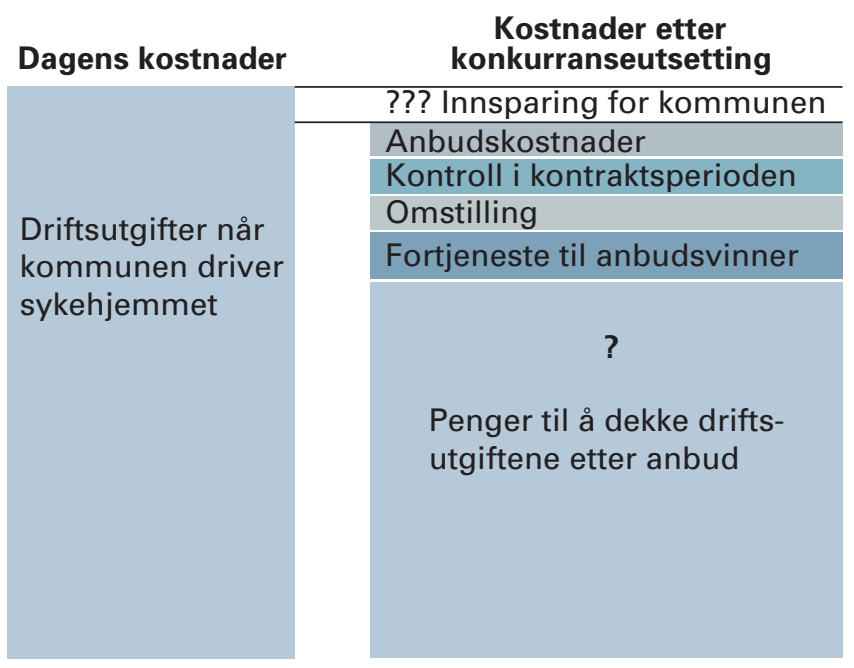

Figur 1 Hvis konkurranseutsetting skal gi lavere kommunal kostnad, må den private drifteren redusere driftsutgiftene så mye at reduksjonen dekker både anbudsvinnerens egen fortjeneste, kommunens innsparing og kommunens nye utgifter til anbudsgjennomføring, kontroll i kontraktsperioden og omstilling

aksjekapital i Klinikk Stokkan la legene Frode Samdal og Ola Evjen inn 30000 kroner hver og finansmannen Ragnar Lyng 40000 kroner. På hjemmesiden sa Lyng at: «Å skape noe nytt handler om nysgjerrighet og utålmodighet - om å spørre hva som kan gjøres bedre, enklere, raskere eller biligere.»

Etter tre års «helserevolusjon» satt de tre igjen med et skattefritt utbytte på 28,5 millioner kroner. «Vi anser oss definitivt ikke som fløteskummere,» sa Frode Samdal til Aftenposten (4). Han påpekte nøkternt at «vi opererer det vi får avtale om å operere (...).»

Det var ikke grenser for hva man kunne få avtale om. Som eksempel påpekte Aftenposten at staten i 2004 betalte private sykehus 12000 kroner for å fjerne en inngrodd tånegl (5). For dette inngrepet fikk et offentlig sykehus 670 kroner fra den samme staten. Vanligvis tok det 15 minutter. Ingen ble verken tiltalt eller straffet for å fikse en så urimelig pengestrøm til privatpraktiserende profitører.

\section{Kommunens utgifter}

Privatisering av sykehjem er også en del av den samme overordnede omdanningsprosessen, men er helt annerledes. Hele institusjoner overlates til et privat selskap i en anbudsperiode. Kommunen får betydelige nye utgifter i tillegg til sykehjemsdriften (fig 1). Driftskostnadene må kuttes kraftig om kommunens samlede utgifter skal bli lavere. Det skjer ikke ved mirakler, men ved at mange underordnede ansatte får mindre lønn enn før. Fordi personalkostnadene - lønn og pensjonspremie - er rundt $80 \%$ av et sykehjems årsbudsjett, må det kuttes der. De ulovlige formene for underbetaling hos Adecco og Incita blir da naturlige og logiske svar.

Egentlig er det selvinnlysende at denne 
formen for modernisering fører til lov- og tariffstridig underbetaling. Ellers kan ikke Adeccos sveitsiske og Incitas norske eiere skumme privat fløte. Aksjonærer og direktører i Adecco, Incita og Klinikk Stokkan har kunnet glede seg over gode resultater. Årsaken er at de som styrer statlig og kommunal ressursbruk ikke synes det viktigste er å sikre gode helsetjenester og god omsorg til de som trenger det.

Norman-utvalgets ideologiske tåkeleggingsarbeid for 20 år siden er en av årsakene til at ikke mange flere så dette mye tidligere. Enda viktigere er de ulike regjeringers allmenne enighet om å gå videre på den veien utvalget pekte ut.

\section{Erling Folkvord}

erfolk@online.no

Oslo

Erling Folkvord (f. 1949) er bystyremedlem i Oslo for partiet Rødt og miljøarbeider i Oslo kommune. Ingen oppgitte interessekonflikter.

\section{Litteratur}

1. Norges offentlige utredninger. NOU 1991: 28. Mot bedre vitende? Effektiviseringsmuligheter i offentlig sektor.

2. Bystyremelding nr. 1/1998. Konkurranse og kvalitet i Oslo kommune.

3. Ingebrigtsen G. Dagsavisen 24.7.2000.

4. Hafstad A, Gedde-Dahl S. - Vi kuttet ventelistene. Aftenposten 9.1.2005. www. aftenposten.no/helse/ article944507.ece (14.4.2011).

5. Gedde-Dahl S, Hafstad A. 12.000 kr for 15 minutters jobb. Aftenposten 21.1.2005. www.aftenposten.no/ helse/article952818.ece (14.4.2011).

Mottatt 24.3. 2011 og godkjent 31.3. 2011. Medisinsk redaktør Siri Lunde. 